\begin{tabular}{|c|c|c|}
\hline & Int.J.Curr.Microbiol.App.Sci (2021) 10(10): 429-438 & \\
\hline IENT & $\begin{array}{l}\text { International Journal of Current Microbiology and Applied Sciences } \\
\text { ISSN: 2319-7706 Volume } 10 \text { Number } \mathbf{1 0}(\mathbf{2 0 2 1 )} \\
\text { Journal homepage: } \underline{\text { http://www.ijcmas.com }}\end{array}$ & 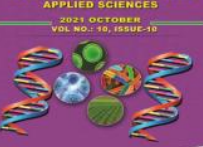 \\
\hline $\begin{array}{l}\text { EXCELLENT } \\
\text { PUBLISHERS }\end{array}$ & & \\
\hline
\end{tabular}

Original Research Article

https://doi.org/10.20546/ijcmas.2021.1010.051

\title{
Effect of Processing Treatments on Functional Properties of Garden Cress (Lepidium sativum L.) Seeds
}

\author{
Vaishnavi* and Radhna Gupta \\ Department of Food Science, Nutrition and Technology CSK Himachal Pradesh Agricultural \\ University, Palampur, Himachal Pradesh, India \\ *Corresponding author
}

\begin{tabular}{|c|}
\hline Keywords \\
\hline $\begin{array}{l}\text { Garden cress, } \\
\text { Treatments, } \\
\text { Total phenols, } \\
\text { Condensed tannin }\end{array}$ \\
\hline Article Info \\
\hline $\begin{array}{l}\text { Accepted: } \\
18 \text { September } 2021 \\
\text { Available Online: } \\
20 \text { October } 2021\end{array}$ \\
\hline
\end{tabular}

A B S T R A C T
Lepidium sativum L. commonly known as garden cress, is a member of the Brassicaceae family. Garden cress is multipurpose plant that has been reported in various ayurvedic texts for its therapeutic and functional properties. Garden cress is one of traditional medicinal plant loaded with nutrients. In the present study, garden cress seeds were quantitatively analyzed as whole, roasted, popped and germinated forms, for selected functional properties viz. total phenols, condensed tannin content and Insoluble dietary fibre profile. The results revealed that different processing treatments improved the nutraceutical properties of garden cress seeds by increasing their total polyphenols and condensed tannins content and also its antioxidant activities. Germinated cress seeds had the highest significant per cent rise of $24.42 \mathrm{mg} / 100 \mathrm{~g}$ total phenols in comparison to raw seeds. There was more than 50 per cent rise $(52.17 \%)$ in condensed tannins content during $48 \mathrm{hrs}$. of germination giving value of $0.35 \mathrm{mg} / 100 \mathrm{~g}$. Roasted seeds contained maximum cellulose (19.26\%) content followed by germinated $(14.10 \%)$, raw $(9.26 \%)$ and popped seeds $(5.92 \%)$.

\section{Introduction}

Since time immemorial, mankind has used plant extracts from different plants to cure many diseases and thus relieve him from physical agony (Ahmed et al., 2007). In our country, the traditional system of medicine plays an important role in health care of rural people for all types of ailments. The healing power of traditional herbal medicines have been realized and documented since Rigveda and Atharbaveda (Bhattacharjya and Borah, 2008). People have been using medicinal plants from time immemorial for the treatment of various types of diseases (Ahmed et al., 2007). Alternative People still dependent upon the traditional medicine available in vegetation and forest to treat ailments. 
Most of the plants possess nutritional as well as medicinal properties and varieties of plants are used for the same purpose. One of traditional medicinal plant loaded with nutrients, is garden cress (Lepidium sativum) belongs to Family: Brassicaceae, Genus: Lepidium. Species: Sativum, Kingdom: Plantae, Division: Magnoliophyta, Class: Magnoliopsida and Order: Brassicales (Shabbir et al., 2018). In India, garden cress plant is known by different vernacular names as chand shura (Sanskrit), chansur (Hindi), halim (Urdu), holan (Punjabi), alian (Kashmiri), haliv (Marathi), aseliyo (Gujrati), candriki (Assamese), chandasura (Oriya), halim (Bengali), allibija (Kannada), aadalu (Telugu), allivirai (Tamil), asali (Malayalam). Garden cress is commonly referred as common cress, garden pepper grass, pepper cress or pepperwort in English, chansur in Hindi and raktabija in Sanskrit as $100 \mathrm{mg}$ of iron is present in $100 \mathrm{~g}$ of garden cress seeds that makes it an excellent source of this important micro mineral (Vaishnavi and Gupta, 2020a). In India, garden cress is grown mainly in the state of Gujarat, Rajasthan, Madhya Pradesh, Uttar Pradesh and Maharashtra in an area of about 5000 hectare (Prajapati and Dave 2018).

The seeds, leaves and roots of garden cress have economic value but its crop is mainly cultivated for its seeds. Garden cress has been considered as an important nutritional and medicinal plant in India since the Vedic era (between 500-1700 B.C.). In Ayurveda the indigenous medicinal system, it is described as hot, bitter, galactagogue and claimed to destroy vata (air) and kapha (phlegm). Seeds are also rich source of omega 3-fatty acids which helps to lower cholesterol in hyper cholesterolemic patients (Agarwal and Sharma (2013).

Lepidium sativum is one such multipurpose plant that has been reported in various ayurvedic texts for its therapeutic and functional properties. Garden cress seed has been used in curing many health related complications by our ancestors. Garden cress seed possesses a wide range of antioxidants. (Prajapati and Dave 2018)

In Unani system of medicine, leaves and seeds of garden cress plant have been reported to possess aperients, diuretics, and aphrodisiac properties as garden cress seeds have positive physiological effects on human health (Chauhan et al., 2012).

Garden cress seeds are categorized under oilseeds and are enriched with macro and micronutrients. The seeds are high in calories (454 Kcal) having $25 \mathrm{~g}$ protein, $24 \mathrm{gm}$ fat, $3 \mathrm{~g}$ dietary fibre and $33 \mathrm{~g}$ of carbohydrates per $100 \mathrm{~g}$ and also has significant amount of minerals viz., $100 \mathrm{mg}$ iron, $377 \mathrm{mg}$ of calcium, $430 \mathrm{mg}$ magnesium and $723 \mathrm{mg}$ of phosphorous and sufficient amount of vitamins, mainly niacin $(14.3 \mathrm{mg})$, riboflavin $(0.61 \mathrm{mg})$ and thiamine $(0.59 \mathrm{mg})$ and per 100 g seeds (Gopalan et al., 2010; Chaudhary and Gupta, 2017).

Its bran has high water holding capacity and high dietary fibre $(74.3 \%)$. When the seeds are soaked in water, they absorb the water rapidly; the mucilage on the seed coat swells and encloses the whole seed with a transparent, colourless covering. The mucilage consists of a mixture of cellulose (18.3\%) and uronic acid containing polysaccharides (Diwakar et al., 2010).

According to Dandge et al., (2012) that seeds of garden cress can be used as food supplement in human diet as garden cress seeds have antioxidant properties, high amount of fibre, protein, good fat as well as high amount of macro and micro elements which increase the utilization of garden cress seeds and consumption of garden cress seeds 
may reduce oxidative damage in the human body when the natural mechanism of antioxidant protection becomes unbalanced by different factors such as ageing, deterioration of various physiological functions may occur resulting in number diseases like cancer, cirrhosis, various inflammatory diseases.

Garden cress seeds can be used as a functional food as they contain natural antioxidants viz. carotenoids and tocopherols that protect the oil from the process of rancidity. Garden cress seeds oil have balanced amount of (MUFA) monounsaturated fatty acids $(37.6 \%)$ and (PUFA) polyunsaturated fatty acids (46.8\%).

Garden cress seeds contain essential fatty acids like arachidic (2-3.5 \%) and linoleic acid (8.5-11.5\%) and alpha linolenic acid (34 $\%)$ which acts as memory boosters.

The major fatty acid in garden cress oil was $\alpha$-Linolenic acid (34\%) followed by oleic (22 $\%)$, eicosanoic $(12 \%)$, linoleic (11.8\%), palmitic $(10.1 \%)$ erucic $(4.4 \%)$, arachidic $(3.4 \%)$ and stearic acids (2.9\%) (Diwaker et al., 2010; Datta et al., 2011).

Garden cress is rich in many phytochemicals, which are responsible for its therapeutic nature and a wide range of positive physiological effects on human health. The seeds are considered to have medicinal values such as galactogogue, anticarcinogenic, antidiabetic, antiasthmatic and antidiarrheal (Patel et al., 2009).

There is growing evidence that functional components of food play an integral role in the link between food and the prevention of diseases but because of lack of awareness regarding the crop and its nutritional and health benefits. It has not received due attention and has remained an under-utilized crop altogether, cultivated and utilized to a lesser extent in Himachal Pradesh (Vaishnavi and Gupta, 2020b).The slight bitterness and astringency of garden cress greatly reduces its acceptability to be incorporated in food products. With this backdrop, cress seeds were subjected to different processing treatments and the effect of these treatments on functional properties viz. total phenols and condensed tannins content and insoluble dietary fibre profile was assessed.

\section{Materials and Methods}

Garden cress seeds used for analysis were procured from the local market which were cleaned manually for removing adhering dirt, dust and foreign particles and seeds were subjected to three treatments viz. popping, roasting and germination. The effect of these treatments on functional properties was analysed.

\section{Processing of garden cress seeds}

\section{Roasting}

The seeds were roasted in a preheated iron skillet at a temperature of $128^{\circ} \mathrm{C}$ for 2.5minutes leading to loss of raw flavour and production of a prominent aroma. Roasted seeds were taken out from the skillet and spread on a tray for rapid cooling.

\section{Popping}

Garden cress seeds were conditioned by soaking overnight in water $(0.5 \mathrm{mg}$ water/g of seeds) in a covered container to gain optimum moisture content. Popping was carried out by dropping the soaked seeds in preheated sand taken in a skillet at $180{ }^{\circ} \mathrm{C}$ and stirring them continuously with the help of wooden spatula until the seeds were properly popped. The average time calculated was 1.15 minutes the popped seeds were quickly separated from the sand using metallic strainer and cooled to room temperature. 


\section{Germination}

Garden cress seeds were spread on a damp muslin cloth and were kept at room temperature $\left(32^{\circ}-35^{\circ} \mathrm{C}\right)$. Regular sprinkling of water was carried out to keep the seeds moist. Seeds took $48 \mathrm{hrs}$ for germination (about $1-1.5 \mathrm{~cm}$ long). Germinated seeds were then dried in tray drier at $55^{\circ} \mathrm{C}$ for 12 hrs. After giving the above treatments, the processed seeds as well as raw garden cress seeds were ground into a fine powder with the help of stainless steel grinder and stored in airtight containers at room temperature for further analysis.

\section{Functional properties}

\section{Total phenols and condensed tannin content}

Total phenol content of raw as well as processed cress seeds was analysed using method of (Julkenen-Tiitto, 1985) where tannic acid was taken as a standard and optical density (OD) was noted at $725 \mathrm{~nm}$ wavelength.

The analysis of condensed tannin content of raw as well as processed cress seeds was carried according to the method of (Broadhurst and Jones, 1978) where catchin was taken as a standard optical density (OD) was noted at $500 \mathrm{~nm}$ wavelength.

\section{In insoluble dietary fibre}

In insoluble dietary fibre profile Neutral Detergent Fibre, Acid Detergent Fibre and Acid Detergent Lignin were determined using (Van Soest and Robertson, 1980) method. While Hemicellulose and Cellulose were calculated using formula

Hemicellulose $=$ NDF-ADF

Cellulose $=$ ADF- Lignin

\section{Statistical analysis}

The analysis of Functional properties of raw as well as processed cress seeds was carried out according to the standard methods in triplicate so as to reduce the experimental error and subjected to statistical analysis for one way analysis of variance (ANOVA) in a completely randomized design at 5 per cent level of probability using statistical software (Sheoran et al., 1998). The values obtained have been reported as mean and standard deviation. Per cent deviation i.e. the effect of treatment on the Functional properties was also assessed and reported in the selected tables.

\section{Results and Discussion}

\section{Total phenols and condensed tannin content}

There is growing evidence that functional components of food play an integral role in the link between food and the prevention of diseases. Among the various functional components, dietary polyphenols, the major group of plant secondary metabolites have received tremendous attention among nutritionists, food scientists and consumers for their roles in human health in the prevention of degenerative diseases, particularly cancers, cardiovascular diseases and neurodegenerative diseases. Polyphenols are chemically characterized as compounds with phenolic structural features having strong antioxidant properties and are divided into a wide range of groups and subgroups owing to their diversity and wide distribution in the plant kingdom. Condensed tannins are proanthocyanidins categorized under flavanols subgroup of flavonoid family of polyphenols and are higher-molecular-weight compounds. The large molecules of condensed tannins are known for their astringent, bitter flavour and have a wide range of health benefits owing to 
their antioxidant properties. The functional properties of unprocessed and processed garden cress seeds were analysed by assessing the total phenols and condensed tannins content of the seeds and the results have been organized in the Table 1.

Raw untreated cress seeds had total phenol content of $42.79 \mathrm{mg} / 100 \mathrm{~g}$ that increased when the seeds were subjected to treatments of roasting, popping and germination, hence significant statistical difference $(\mathrm{p} \leq 0.05)$ was calculated when the values of the treatments were compared with each other.

As clear from the difference in values, germinated seeds had the highest significant per cent rise of 24.42 in comparison to raw seeds. During seed sprouting, a multitude of biochemical processes takes place, leading to radical changes in primary and secondary metabolites composition which could result in a change of intrinsic phenolic compounds profile and antioxidant activity (Jian et al., 2009). Gawlik-Dziki and Swieca(2011) studied sprouts of selected plants as a source of bioavailable antioxidants and found that cress had higher amounts of bioaccessible total phenolics and flavoinoids content followed by radish, alfaalfa and lentil. Tajoddin et al., (2014) investigated the effect of soaking and germination on the polyphenol content of mung bean cultivars. They found that soaking reduced the total polyphenols, whereas germination for $48 \mathrm{~h}$ increased total polyphenol content by 41-76\%.On the contrary side, Naveena and Bhaskarachary (2013) perceived that soaking and germination processes significantly $(\mathrm{p}<0.001)$ reduced the total and individual polyphenolic contents in the selected commonly consumed millets and legumes. Rajshri and Haripriya (2018) analyzed total phenolic content of the untreated germinated and roasted garden cress seed powder to values of $43.17,51.44$ and $45.76 \mathrm{mg} / 100 \mathrm{~g}$. There was $19.15 \%$ and 5.99
$\%$ increase in the total phenolic content of the garden cress seed powder on germination and dry roasting.

Garden cress seeds roasted at a temperature of $128^{\circ} \mathrm{C}$ for 2.5 minutes led to 4.04 per cent rise in total phenols thus recording value of 44.52 $\mathrm{mg} / 100 \mathrm{~g}$. Increase in total phenolic content on roasting may be due to an increase in the extractability of bound phenolics by the thermal degradation of cellular constituents. Hassan and Rahman (2019) observed a significant increase in total phenolics content in garden cress samples when they were roasted at time intervals of 5,10 and 15 minutes duration. They suggested that that roasting causes decomposition and liberation of some compounds as a result of heat or conversion between isomers which result in increasing or decreasing in contents of phytochemical components.

The total phenolic content exhibited a significant appreciation of 18.55 per cent during popping of garden cress seeds with value of $50.73 \mathrm{mg} / 100 \mathrm{~g}$ and a per cent rise of 18.55. Menacho et al., (2018) observed a noticeable increase in flavonoid levels in popped quinoa. Panwar and Guha (2014) reported that the total phenolic content in garden cress seeds varied in popped and germinated seeds as compared to native seeds. They analysed higher TPC content in popped (2.11g GAE/100g) and lower in germinated $(1.69 \mathrm{~g} \mathrm{GAE} / 100 \mathrm{~g})$ as compared to raw seeds $(1.78 \mathrm{~g} \mathrm{GAE} / 100 \mathrm{~g})$. The findings in the present investigation demonstrated that the processed garden cress seeds are a good source of polyphenols, thus having great potential as a source of natural antioxidants.

As for total polyphenols, the condensed tannins content also increased with the different processing treatments. Native garden cress seeds had concentration of $0.23 \mathrm{mg} / 100 \mathrm{~g}$ that incrementally increased to $0.25,0.29$ with 
calculated per cent rise of $8.69,26.08$ respectively in roasted $\left(\mathrm{T}_{2}\right)$ and popped $\left(\mathrm{T}_{3}\right)$ treatments. There was more than 50 per cent rise $(52.17 \%)$ in condensed tannins content during $48 \mathrm{hrs}$ for germination giving value of $0.35 \mathrm{mg} / 100 \mathrm{~g}$.

Statistical analysis at 5 per cent level of probability indicated a significant difference between native and processed cress seeds and also among the processed variants. Studies done by Zhang et al., (2015) and Tajoddin et al., (2014) too reported a progressive increase in the phenolic and tannin content during germination of different seeds.

Different processing treatments used in present investigation i.e. roasting, popping and germination improved the nutraceutical properties of garden cress seeds by increasing their total polyphenols and condensed tannins content and also its antioxidant activities.

\section{Insoluble dietary fibre profile}

Insoluble fibre is indigestible carbohydrate component that adds bulk to our stools and hence prevents constipation and reduces the risk of haemorrhoids and diverticulosis. Insoluble fibres found in our diet include cellulose, hemicellulose and lignin.

Acid detergent Fibre (ADF) determination measures the least digestible portion of food materials which includes lignin, cellulose, silica and insoluble forms of nitrogen but not hemicellulose. Nutrient Detergent Fibre (NDF) determination involves determination of plant pectins, proteins, sugar and lipids but not cellulose, lignin and hemi-cellulose. The profile of these functional components was also assessed for garden cress seeds and the results obtained have been presented in Table 2.

\section{Cellulose}

Cellulose is a structural polysaccharide made up of repeating units of glucose with $\beta$ 1-6 linkage which make up most of the plant cell wall and is the major source of needed fibre in our diet. Data in Table 2 depicts that cellulose content was highest in unprocessed garden cress seeds (12.67\%) and reduced to levels of 10.36, 9.49 and 8.04 per cent when the seeds were subjected to processing methods of roasting, popping and germination. Therefore, per cent reduction of 18.23, 25.09, and 36.54 was worked out for these variants. Significant difference was observed when processed garden cress seeds were compared statistically with each other as well as with the native unprocessed seeds. The processing conditions like temperature, soaking and cooking can change the dietary fibre composition considerably, thereby affecting the physicochemical and nutritive value of dietary fibre using chemical, mechanical, enzymatic and thermal processes (Ozyurt and Otles, 2016).

\section{Hemicellulose}

Hemicelluloses are polysaccharides containing pentoses, hexoses and uronic acid that help in strengthening of cell walls by interacting with cellulose. Different processing treatments influence and alter the physicochemical properties of dietary fibre and improve their functionality (Dhingra et al., 2012). 
Table.1 Total phenols and condensed tannin content of unprocessed and processed garden cress seeds (mg/100g, DW basis)

\begin{tabular}{|c|c|c|c|c|c|c|}
\hline \multirow{2}{*}{ Parameters } & \multicolumn{4}{|c|}{ Treatments } & Mean & $\begin{array}{c}\text { C.D } \\
(\boldsymbol{p} \leq \mathbf{0 . 0 5})\end{array}$ \\
\cline { 2 - 7 } & $\mathbf{T}_{\mathbf{1}}$ & $\mathbf{T}_{\mathbf{2}}$ & $\mathbf{T}_{\mathbf{3}}$ & $\mathbf{T}_{\mathbf{4}}$ & & 0.181 \\
Total & $42.79 \pm 0.239$ & $\begin{array}{c}44.52 \pm 0.274 \\
(+4.04)\end{array}$ & $\begin{array}{c}50.73 \pm 0.179 \\
(+18.55)\end{array}$ & $\begin{array}{c}53.24 \pm 0.278 \\
(+24.42)\end{array}$ & $47.82 \pm 0.246$ & \\
\hline $\begin{array}{c}\text { Phenols } \\
\text { Condensed } \\
\text { Tannins }\end{array}$ & $0.23 \pm 0.004$ & $\begin{array}{c}0.25 \pm 0.003 \\
(+8.69)\end{array}$ & $\begin{array}{c}0.29 \pm 0.002 \\
(+26.08)\end{array}$ & $\begin{array}{c}0.35 \pm 0.004 \\
(+52.17)\end{array}$ & $0.28 \pm 0.003$ & 0.011 \\
\hline
\end{tabular}

Data are expressed as the mean \pm standard deviation. Data in parenthesis shows per cent deviation.

Table.2 Insoluble dietary fibre profile of unprocessed and processed garden cress seeds (\% DW basis)

\begin{tabular}{|c|c|c|c|c|c|c|}
\hline \multirow[t]{2}{*}{ Parameters } & \multicolumn{4}{|c|}{ Treatments } & \multirow[t]{2}{*}{ Mean } & \multirow{2}{*}{$\begin{array}{c}\text { C.D } \\
(p \leq 0.05)\end{array}$} \\
\hline & $\mathbf{T}_{1}$ & $\mathbf{T}_{2}$ & $\mathbf{T}_{3}$ & $\mathbf{T}_{4}$ & & \\
\hline Cellulose & $12.67 \pm 0.163$ & $\begin{array}{c}10.36 \pm 0.318 \\
(-18.23)\end{array}$ & $\begin{array}{c}9.49 \pm 0.081 \\
(-25.09)\end{array}$ & $\begin{array}{c}8.04 \pm 0.083 \\
(-36.54)\end{array}$ & $10.14 \pm 0.188$ & 0.622 \\
\hline Hemicellulose & $9.26 \pm 0.384$ & $\begin{array}{c}19.26 \pm 0.296 \\
(+107.99)\end{array}$ & $\begin{array}{c}5.92 \pm 0.044 \\
(-36.06)\end{array}$ & $\begin{array}{c}14.10 \pm 0.321 \\
(+52.26)\end{array}$ & $11.84 \pm 0.292$ & 0.962 \\
\hline Lignin & $6.09 \pm 0.214$ & $\begin{array}{c}6.63 \pm 0.186 \\
(+8.86)\end{array}$ & $\begin{array}{c}4.11 \pm 0.196 \\
(-32.51)\end{array}$ & $\begin{array}{c}2.56 \pm 0.233 \\
(-57.96)\end{array}$ & $4.84 \pm 0.208$ & 0.690 \\
\hline
\end{tabular}

Data are expressed as the mean \pm standard deviation. Data in parenthesis shows per cent deviation.

Fig.1 Standard curve for Condensed Tannins

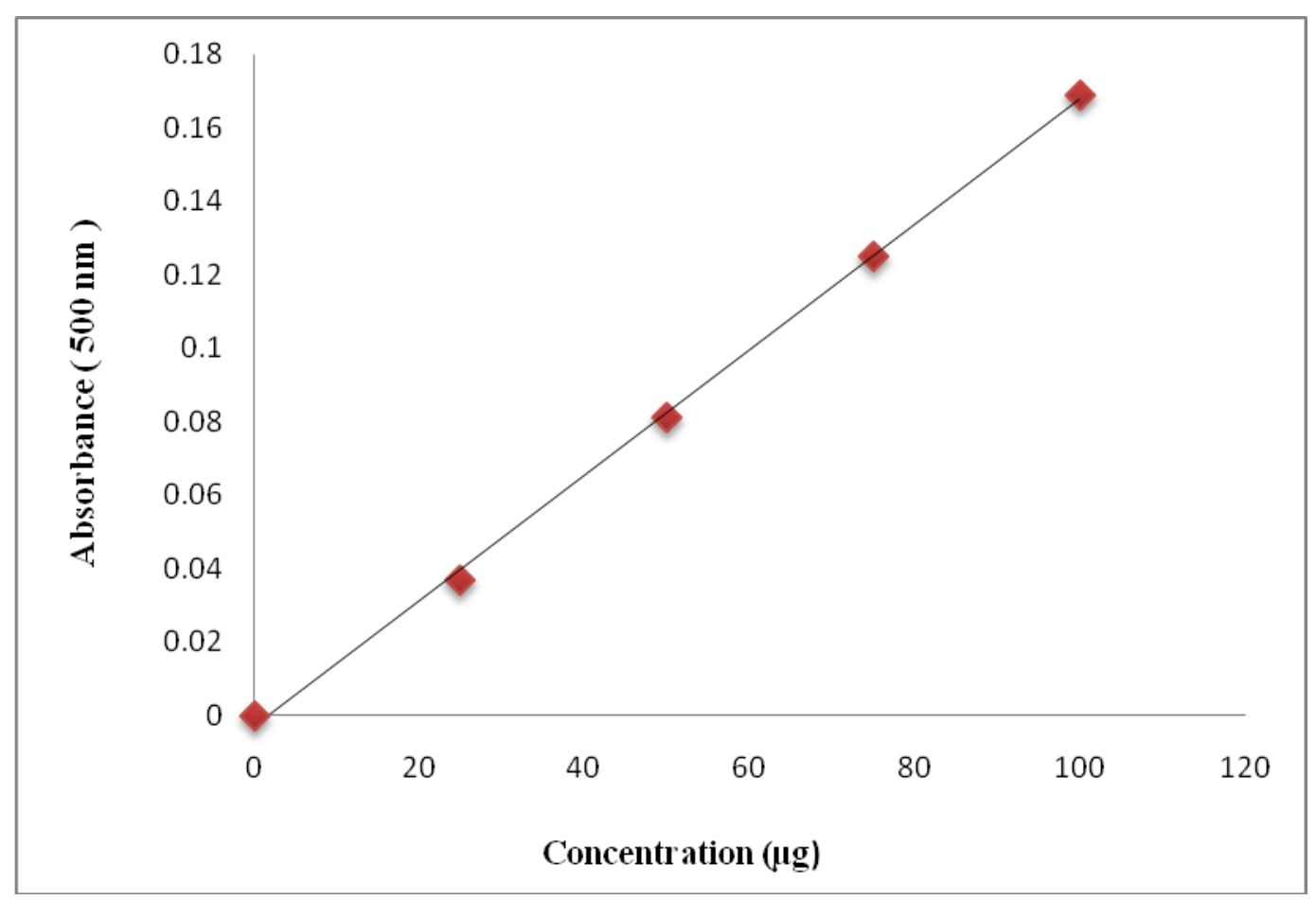


Fig.2 Standard curve for Total Phenols

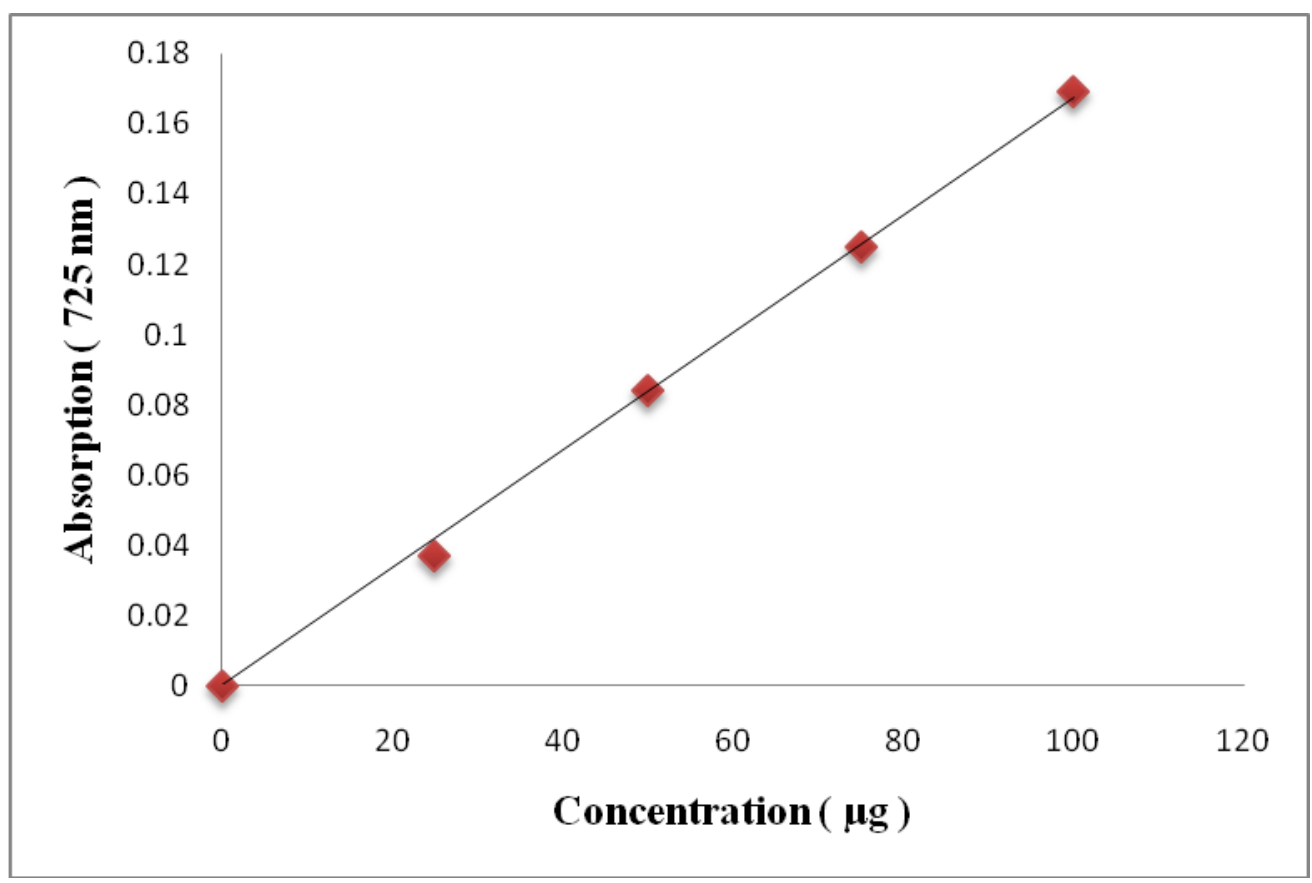

Roasted garden cress seeds contained maximum cellulose (19.26\%) content followed by germinated $(14.10 \%)$, raw $(9.26 \%)$ and popped seeds $(5.92 \%)$. Per cent increment of 107.99 and 52.26 was calculated for roasted $\left(\mathrm{T}_{2}\right)$ and germinated $\left(\mathrm{T}_{4}\right)$ treatments while a decrease of 36.06 was observed for popped one (Table 4.8). Herranz et al., (2006) evaluated the effect of processing on dietary fibre content of raw and boiled vegetables. They observed that boiling increased the NDF, ADF and hemicellulose content.

\section{Lignin}

Lignin is a part of the plant cell and contributes to the structural rigidity to the plant and is responsible for the resistance of cell wall to microbial degradation. Lignin has a protective role against many diseases. Many studies show the beneficial effect of lignin in human health. Results of lignin content of unprocessed and processed garden cress seeds are presented in the Table 4.8. When statistically analysed, a significant difference was observed in the lignin content of popped and germinated seeds when compared with unprocessed seeds. No significant alteration was observed between roasted and raw cress seeds. Per cent deviation of $+8.86,-57.96$ and -32.51 was worked out for roasted, germinated, and popped variants. Guha and Dhoke(2014) analysed carbohydrate profile of small sized, oval shaped garden cress seeds and reported 17.9 and $29.4 \%$ insoluble and soluble lignin, $35.57 \%$ per cent neutral detergent fibre, $27.3 \%$ per cent acid detergent fibre and $8.4 \%$ hemicellulose.

Processed garden cress seeds were analyzed for its functional properties in order to attain the best processed form of seeds for better utilization. From the present study it can be concluded that processing treatments can substantially improve the functional properties profile of garden cress seeds. Germinated cress seeds had the highest significant per cent rise of $24.42 \mathrm{mg} / 100 \mathrm{~g}$ total phenols in comparison to raw seeds. There was more than 
50 per cent rise $(52.17 \%)$ in condensed tannins content during $48 \mathrm{hrs}$. of germination giving value of $0.35 \mathrm{mg} / 100 \mathrm{~g}$. Cellulose content was highest in unprocessed seeds (12.67\%) and reduced to levels of $10.36,9.49$ and 8.04 per cent when the seeds were subjected to processing methods of roasting, popping and germination. Roasted seeds contained maximum cellulose $(19.26 \%)$ content followed by germinated (14.10\%), raw $(9.26 \%)$ and popped seeds $(5.92 \%)$. This treatment also had highest lignin content $(6.63 \%)$ in comparison to $\mathrm{T}_{1}(6.09 \%), \mathrm{T}_{3}$ $(4.11 \%)$ and $\mathrm{T}_{4}(2.56 \%)$.

\section{References}

Agarwal and S. Sharma (2013) Garden cress (Lepidium sativum L.). A nonconventional traditional plant item for food product. Indian journal of traditional knowledge 12, 699 - 706

Ahmed, M B. Uddin \& M R. Tito (2007) Medicinal plant diversity and local healthcare among the people living in and around a conservation area of Northern Bangladesh, Int J For Usuf Mng 8(2), 5063

Ballabh B and Chaurasia O. P. (2007). "Traditional medicinal plants of cold desert Ladakh-Used in treatment of cold, cough and fever," Journal of Ethnopharmacology 112 (2), 341-345

Broad-hurst and W T. Jones (1978) Analysis of condensed tannins using acidified vanillin. Journal of the Science of Food and Agriculture 29,788-794

Chauhan, S Sharma, N Agarwal, S Chauhan and B Chauhan (2012) A study on potential hypoglycemic and hypolipidemic effects of Lepidium Sativum (Garden Cress) in Alloxan induced diabetic rats. American Journal of Pharm Tech Research 2, 522535

Bhattacharjya, P. C. Borah., Indian J. of Traditional Knowledge (2008) 7(3), 501504

Dandge, P J Kasabe, P N Patil and D D Kamble
(2012) Nutritional, elemental analysis and antioxidant activity of garden cress seeds. International Journal of Pharmacy and Pharmaceutical Sciences 4, 392-395

Datta, B T Diwakar, S Viswanatha, K N Murthy and K A. Naidu (2011) Safety evaluation studies on Garden cress (Lepidium sativum L.) seeds in Wistar rats. International Journal of Applied Research in Natural Products 4, 37-43

Dhingra, M Michael, H Rajput and R T. Patil (2012) Dietary fibre in foods: a review. Journal of Food Science and Technology 49, 255-266

Diwakar, P K Dutta, P K Lokesh, and K A. Naidu (2010) Physicochemical properties of garden cress (Lepidium sativum L.) seed oil. Journal of the American Oil Chemists' Society 87,539-548

Doke and M. Guha (2014) Garden cress (Lepidium sativum L.) seed-An important medicinal source: A review. Journal of Natural Product and Plant Sources 4, 6980

Gawlik-Dziki and M. Świec (2011) Sprouts of selected plants as a source of bioavailable antioxidants and lipoxygenase inhibitors. Annales University. M. CurieSkłodowska Lublin - Polonia 8 (3), 161168

Hassan and A M. Abdel-Rahman (2019) The Influence of Dry Roasting Process on Chemical and Nutritional Properties of Garden Cress Seeds Flour. International Advanced Research Journal in Science, Engineering and Technology 6, 73-82

Herranz, C Vidal-Valverda and E. RojasHidalgo (2006) Cellulose, hemicellulose and lignin content of raw and cooked processed vegetables. Journal of Food science 48, 274-275

Jian, G X, R T Cheng, P H Qing, Y L Ji, D W Xiang and D T Xiang (2009) Dynamic changes in phenolic compounds and antioxidant activity in oats (Avena nuda L.) during steeping and germination. Journal of Agricultural and Food Chemistry 57, 10392- 10398

Julkunen -Tiitto R. (1985) Phenolic constituents 
in the leaves of Northern Williows: methods of analysis of certain phenolics. The Journal of Agricultural and Food Chemistry 33, 213-217

Menacho L M P, Dueñas M, Peñas E, Juana F and Villaluenga C M. 2018. Effect of Dry Heat Puffing on Nutritional Composition, Fatty Acid, Amino Acid and Phenolic Profiles of Pseudocereals Grains. Polish Journal of Food and Nutrition Sciences 68, 289-297

Naveena N. and Bhaskarachary K. 2013. Effects of soaking and germination of total and individual polyphenols content in the commonly consumed millets and legumes in India. International Journal of Food and Nutritional Sciences 2, 12-19

Ozyurt and S Otles (2016) Effect of food processing on the physicochemical properties of dietary fibre. Acta Scientiarum Polonorum Technologia Alimentaria 15, 233-245

Panwar and M Guha. (2014). Effect of processing on nutraceutical properties of garden cress (Lepidium sativum L.) seeds. International Journal of Pharmacy and Pharmaceutical Sciences. 6, 315-318

Patel, U., Kulkarni, M., Undale, V. and Bhosale, A. (2009). Evaluation of diuretic activity of aqueous and methanol extracts of Lepidium sativum garden cress (Cruciferae) in rats. Tropical Journal of Pharmaceutical Research 8, 215-219

Prajapati and P H Dave (2018) Therapeutic and nutritional importance of garden cress seed. Journal of Pharmacognosy and Phytochemistry 7, 140-143

Rajshri V S and Haripriya A (2018) Effect of processing on the functional properties of Garden cress seeds and development of garden cress seed flour incorporated Instant soup mix and RTC Chapati. International Journal of Food Science and Nutrition 3, 130-135

Sheoran, O. P., D. S., Tonk, Kaushik, L. S., Hasija, R. C. and Pannu, R. S. (1998). Statistical Software Package for Agricultural Research Workers. Department of Mathematics Statistics, CCS HAU, Hisar P 139-143

Tajoddin, S Manohar \& J Lalitha (2014) Effect of Soaking and Germination on Polyphenol Content and Polyphenol Oxidase Activity of Mung Bean (Phaseolus aureus L.) Cultivars Differing in Seed Color. International Journal of Food Properties. 17, 782-790

Vaishnavi, R. Gupta (2020a) Botanical description of garden cress (Lepidium sativum L.) plant and physical characteristics of its seeds. Journal of Pharmacognosy and Phytochemistry. 9(5), 2424-2428

Vaishnavi, R. Gupta (2020b). Effect of processing treatments on nutritional profile of garden cress (Lepidium sativum L.) seeds. International Journal of Chemical Studies. 8(4), 2831-2835.

Van Soest, P. J and Robertson (1980) System of analysis for evaluating fibrous feeds. In: Standardization of Analytical Methodology in Feed (Pigden, W.J., Balch, C. C \& Graham, M., Eds.). International Research Development Center, Ottawa, Canada. P 49-60

Zhang, Z. Xu, Y Gao, T. Yang (2015) Effect of germination on the nutritional properties and antioxidant activities of buckwheat. Journal of Food Science. 80, 1111-1119.

\section{How to cite this article:}

Vaishnavi and Radhna Gupta. 2021. Effect of Processing Treatments on Functional Properties of Garden Cress (Lepidium sativum L.) Seeds. Int.J.Curr.Microbiol.App.Sci. 10(10): 429-438. doi: https://doi.org/10.20546/ijcmas.2021.1010.051 